\title{
The AIRSAN Project - Efficient, coherent EU level response to public health threats in air transport
}

A Milde-Busch (AIRSAN@rki.de) ${ }^{1}$, A Gilsdorf ${ }^{1}$

1. Department for Infectious Disease Epidemiology, Robert Koch Institute

Citation style for this article:

Milde-Busch A, Gilsdorf A. The AIRSAN Project - Efficient, coherent EU level response to public health threats in air transport. Euro Surveill. 2014;19(38):pii=20913. Available online: http://www.eurosurveillance.org/ViewArticle.aspx?Articleld=20913

The Ebola virus disease epidemic in West Africa since spring 2014 illustrates once again the need to be well prepared for cross-border public health threats. One challenge is to contain the spread of the disease by a coordinated international response which should entail sound cooperation between the public health and the aviation sector. The AIRSAN Project, funded by the European Commission, aims to ensure an efficient, coherent response at EU-level to public health threats in air transport. Project partners are public health authorities, airlines, airport managements and international organisations, e.g. the World Health Organization (WHO), the International Civil Aviation Organization (ICAO) and the International Air Transport Association (IATA).

The AIRSAN Project provides the AIRSAN website; an open-access website for dissemination of information for public health and civil aviation authorities, airlines and airports: http://www.airsan.eu/

The AIRSAN Project website also provides access to:

- AIRSAN Guidance Documents: The AIRSAN Project develops guidance documents that focus on managing public health threats in air transport which will be made available on the AIRSAN website. As an interim result, the AIRSAN bibliography has been created and is available online. The bibliography makes public health action-orientated information in the aviation sector quickly accessible: http://www.airsan.eu/Resources/Bibliography/ Search.aspx In the current Ebola outbreak situation the following example illustrates the benefit of the AIRSAN bibliography: a competent public health authority wants to know how to manage a flightpassenger with suspected Ebola virus disease at an airport. The keyword-search "Management of suspect or affected travellers (at-airport)" reveals 14 documents with information about the specific topic. In case the flight-passenger is confirmed with Ebola virus disease the keyword "Contact tracing" can be searched and results include documents like the Risk Assessment Guidelines for Infectious Diseases Transmitted on Aircraft
(RAGIDA) [1] which gives specific advice on the definition of close contacts in cases of viral haemorrhagic fevers.

- The AIRSAN Network: The AIRSAN Project brings together competent public health authorities, civil aviation authorities, airport management and airlines across EU Member States in form of a network. Interested authorities are invited to register here for the AIRSAN Network: http://www. airsan.eu/ContactUs/RegistertotheAirsanNetwork. aspx. Registered members can use the passwordprotected AIRSAN Communication Platform to exchange information, e.g. on airport exercises or developed information material and to discuss topics concerning public health in the aviation sector.

- The AIRSAN Training Tool: The AIRSAN Project is developing a training tool that will support authorities and companies with the implementation of the AIRSAN Guidance Documents. The AIRSAN Training Tool will also be made available on the AIRSAN website.

In summary, the AIRSAN Project facilitates the implementation of the International Health Regulations (2005) [2] and the Decision 1082/2013 [3] in EU Member States.

References

1. European Centre for Disease Prevention and Control (ECDC) Risk assessment guidelines for diseases transmitted on aircraft. 2nd ed. Stockholm: ECDC; 2010.Available from: http:// www.ecdc.europa.eu/en/publications/Publications/1012_GUI_ RAGIDA_2.pdf.

2. World Health Organization (WHO). International Health Regulations (2005). Second edition. Reprinted 2008. Geneva: WHO; 2008. Available from: www.who.int/ihr/9789241596664/ en/index.html

3. The European Parliament and of the Council of the European Union. Decision No 1082/2013/EU of the European Parliament and of the Council of 22 October 2013 on serious cross-border threats to health and repealing Decision No 2119/98/EC. Offical Journal of the European Union. Luxembourg: Publications Office of the European Union. 5.11.2013:L 293. Available from: http://eur-lex.europa.eu/LexUriServ/LexUriServ.do?uri=0J:L:2 013:293:0001:0015:EN:PDF 